\title{
ISOLASI SENYAWA ANTIOKSIDAN DARI RIMPANG JAHE BALIKPAPAN (Etlingera balikpapanensis)
}

\author{
Dina Sofia*, Wisnu Cahyo Prabowo, Laode Rijai \\ Laboratorium Penelitian dan Pengembangan FARMAKA TROPIS \\ Fakultas Farmasi, Universitas Mulawarman, Samarinda, Kalimantan Timur \\ *email :dinsofiaaa@gmail.com
}

\begin{abstract}
ABSTRAK
Jahe balikpapan (Etlingera balikpapanensis) adalah tumbuhan yang banyak ditemukan di Balikpapan, Kalimantan Timur, Indonesia. Tumbuhan ini belum diteliti khasiat dan kandungannya. Memperoleh senyawa antioksidan dari rimpang jahe balikpapan. Simplisia rimpang jahe balikpapan diekstraksi secara maserasi. Ekstrak difraksinasi dengan n-heksana, etil asetat, dan metanol. Fraksi etil asetat diisolasi berdasarkan aktivitas antioksidannya. Isolasi senyawa menggunakan metode kromatografi kolom. DPPH disemprotkan pada plat KLT untuk mengetahui aktivitas antioksidan isolat. Kemurnian isolat diuji dengan KLT 2 dimensi. Diperoleh senyawa antioksidan yang memiliki aktivitas penghambatan terhadap DPPH.
\end{abstract}

Kata kunci : Rimpang Jahe balikpapan, Etlingera balikpapanensis dan Antioksidan

\section{ABSTRACK}

Jahe Balikpapan (Etlingera balikpapanensis) was plants that found in Balikpapan, East Kalimantan, Indonesia. This plant has not been studied about efficacy and content. Obtain the Antioxidant Compounds from jahe balikpapan rhizome. Simplicia of jahe balikpapanrhizome extracted with maceration. Fractionated extracts with $n$-hexane, ethyl acetate, and methanol. Ethyl acetate fraction was isolated by activities antioxidants. Column chromatography used for the isolation of antioxidant compunds. The inhibitory activity of DPPH guided by spraying the TLC plate. The purity test isolates used two-dimensional TLC. Obtained the antioxidant compounds that have inhibitory activity to DPPH.

Keywords: Jahe balikpapan rhizome, Etlingera balikpapanensis and Antioxidants

\section{PENDAHULUAN}

Zingiberaceae di Indonesia secara umum dikenal dengan jahe-jahean, mempunyai ciri khas pada rimpangya yang mengandung minyak menguap atau berbau aromatik. Tumbuhan ini umumnya banyak dimanfaatkan oleh masyarakat sejak dulu hingga sekarang karena mempunyai potensi ekonomi yang penting yaitu antara lain sebagai obat tradisional seperti jamu, bahan ramuan herbal, rempah-rempah, bumbu masak, dan penyedap makanan (Siregar, 2008).

Berbagai spesies dari genus Etlingera yang paling terkenal adalah Etingera elatior. Menurut Abdelwahab (2010), telah diidentifikasi senyawa golongan flavonoid dari daun $E$. 
elatior (Zingiberaceae) yaitu kaempferol 3-glucuronide, quercetin 3-glucuronide, quercetin 3-glucoside dan quercetin 3-rhamnoside.

Maimulyanti (2015), menyatakan nilai $\mathrm{IC}_{50}$ ekstrak bunga E. elatior adalah 21.14 $\mu \mathrm{g} / \mathrm{mL}$ dan hasil analisis kromatogram GC-MS pada ekstrak yaitu mengandung 1-dodecanol (13.82\%), dodecanal (12.10\%), 17-pentatriacontene (10.52\%).

Menurut Jafaar (2007), daun dari E. elatior mengandung $\beta$-pinena (19.7\%), karyofilena (15.36\%) dan (E)- $\beta$-farnesena (27.90\%), batangnya mengandung 1,1dodekanadiol diasetat (34.26\%) dan (E)-5-dodekana (26.99\%) dan rimpangnya mengandung 1,1- dodekanadiol diasetat (masing-masing $24.38 \%$ dan $40.37 \%$ ) dan siklododekana (masing-masing $47.28 \%$ dan $34.45 \%$ ).

Studi fitokimia lainnya mengenai rimpang dari E. elatior yaitu telah diisolasi senyawa 1,7-bis(4-hydroxyphenyl)-2,4,6-heptatrienone, de-methoxycurcumin, 1,7-bis(4-hydroxyphenyl)-1,4,6-heptatrien-3-one yang diketahui memiliki aktivitas antioksidan yang lebih baik daripada $\alpha$-tokoferol dengan metode FTC (Ferri Tiosianat) (Mohammad, 2005).

Jahe Balikpapan (Etlingera balikpapanensis) adalah tanaman endemik Kalimantan Timur yang masih belum diteliti mengenai aktivitas kandungan senyawa didalamnya. Berdasarkan uraian di atas, kemungkinan Jahe Balikpapan memiliki kesamaan fisiologis dengan E.elatior karena berada dalam genus yang sama. Sehingga penelitian ini bertujan untuk mengisolasi senyawa antioksidan pada jahe balikpapan.

\section{METODE PENELITIAN}

\section{Bahan Penelitian}

Rimpang jahe balikpapan (Etlingera balikpapanensis) diperoleh di hutan balikpapan, Kalimantan Timur, Indonesia. Bahan penelitian antara lain metanol, n-heksana, etilasetat, kloroform, etanol, $\mathrm{H}_{2} \mathrm{SO}_{4}, \mathrm{DPPH}$, asam borat, asam sitrat, $\mathrm{KOH}$, asam asetat anhidrat, $\mathrm{FeCl}_{3}$, Kromatografi Lapis Tipis (Si-gel $60 \mathrm{GF}_{254}$ Merck ), silica gel H-60 Merck .

\section{Alat Penelitian}

Peralatan yang digunakan atara lain maserator, Rotary evaporator (Buchi ),

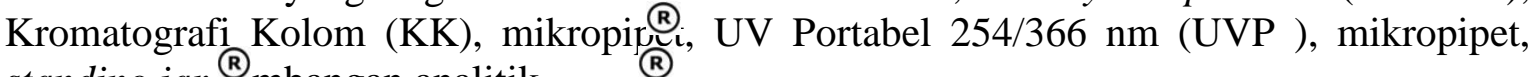
standing jar, $\stackrel{\circledR}{\circledR}$ mbangan analitik.

\section{Cara Kerja}

\section{Uji Determinasi}

Rimpang jahe balikpapan yang diperoleh di Balikpapan, Kalimantan Timur, Indonesia dilakukan determinasi di Balai Penelitian dan Pengembangan Teknologi Konservasi Sumber Daya Alam Kalimantan Timur (Balitek KSDA Kaltim).

\section{Persiapan Bahan}

Sampel rimpang jahe balikpapan (Etlingera balikpapanensis) dibersihkan, dipotong kecil-kecil dan dikeringkan dengan cara diangin-anginkan.

\section{Ekstraksi dan Fraksinasi}

Sebanyak $1,108 \mathrm{~kg}$ sampel dimaserasi dengan pelarut metanol. Ekstrak cair yang diperoleh dipekatkan dengan rotary evaporator sehingga diperoleh ekstrak kental metanol. Diuapkan pelarut pada ekstrak kental dengan cara diangin-anginkan hingga menjadi ekstrak kering 96,8 gram. 
Ekstrak kering tersebut difraksinasi berdasarkan perbedaan gradien pelarut dengan menggunakan n-heksan hingga jenuh lalu etil asetat dan metanol.

\section{Isolasi Senyawa}

Fraksi etil asetat dipantau pola pemisahannya menggunakan KLT. Metode isolasi yang digunakan antara lain kromatografi kolom dengan fase diam silika gel $\mathrm{H}-60$ dan fase geraknya secara gradien yaitu dari heksan:etil asetat dan kloroform: metanol. Uji kemurnian isolat digunakan KLT 2 dimensi.

\section{Pengujian Aktivtas Antioksidan}

\section{Pembuatan DPPH}

Ditimbang 2,5 mg DPPH dan dilarutkan dengan metanol hingga $25 \mathrm{~mL}$. Dipindahkan larutan kedalam wadah penyemprot.

\section{Pengujian Sampel}

Ditotolkan ekstrak, fraksi etil asetat, sub fraksi 2 (SF 2) dan isolat A pada plat KLT dan dielusikan dengan eluen n-heksan:etil asetat (8:2). Disemprotkan DPPH pada plat KLT, diamati aktivitas antioksidan senyawa pada plat KLT. Senyawa dikatakan memiliki aktivitas antioksidan jika nodanya berwarna kuning dengan latar plat KLT berwarna ungu.

\section{Skrining Fitokimia}

Pengujian golongan senyawa isolat A dengan menggunakan reagen semprot seperti Lieberman-Burchard, $\mathrm{KOH} 10 \%, \mathrm{FeCl}_{3}$, sitroborat.

\section{HASIL DAN PEMBAHASAN}

Isolasi senyawa dimulai dengan proses maserasi menggunakan metanol, dilanjutkan fraksinasi menggunakan gradien pelarut. Fraksi etil asetat diisolasi menggunakan kromatografi kolom menggunakan campuran gradien n-heksan:etil asetat dan kloroform : metanol sehingga diperoleh sub fraksi 1-12. Subfraksi 2 dikristalisasi menggunakan pelarut $\mathrm{n}$-heksan dan etil asetat sehingga diperoleh isolat A (48 mg).

Aktivitas senyawa terdeteksi pada hasil penyemprotan radikal DPPH ditunjukkan pada gambar 1, terdapat warna kuning pucat pada spot senyawa dengan latar belakang berwarna ungu.

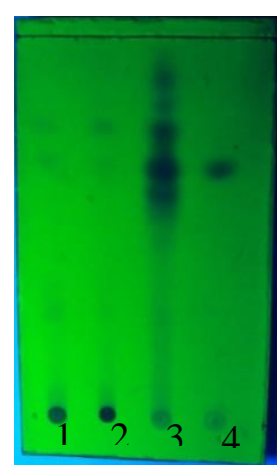

(a)

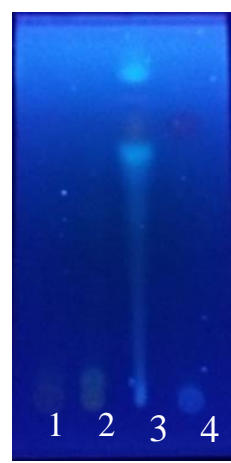

(b)

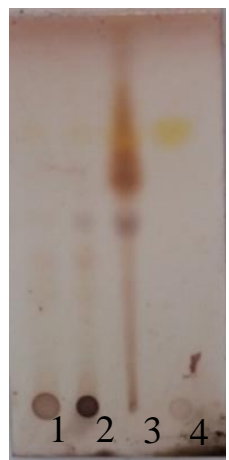

(c)

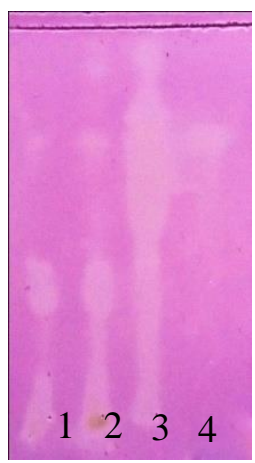

(d)

Gambar 1. Profil KLT ekstrak (1), fraksi etil asetat (2), SubFraksi 2 (3) dan isolat A (4) pengamatan pada UV $254 \mathrm{~nm}$ (a), UV $366 \mathrm{~nm}$ (b), penampak bercak $\mathrm{H}_{2} \mathrm{SO}_{4} 10 \%$ (c), dan pengujian aktivitas antioksidan terhadap DPPH (d). 
Metode yang dapat digunakan untuk uji kemurnian senyawa hasil yaitu kromatografi lapis tipis dua dimensi (KLT 2 dimensi), metode ini sering diterapkan untuk menguji kemurnian dari suatu senyawa dimana senyawa yang dikatakan murni adalah senyawa yang menghasilkan satu bercak setelah dilakukan proses elusi menggunakan eluen tertentu, dalam Candra (2012).

Uji kemurnian isolat A dilakukan dengan KLT 2 dimensi dengan eluen sistem pertama n-heksan : kloroform (5:5) dan eluen sistem kedua heksan : etil asetat (8:2), berupa kristal putih.

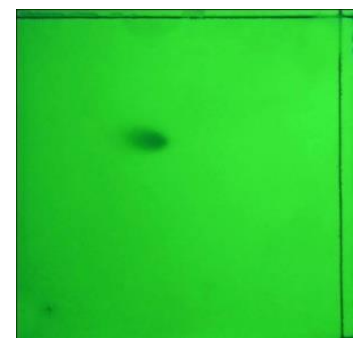

(a)

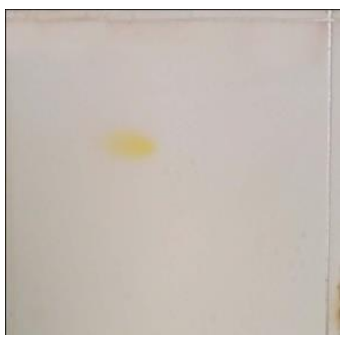

(b)

Gambar 2. Profil KLT 2 dimensi isolat A pada UV $254 \mathrm{~nm}$ (a) dan penampak bercak $\mathrm{H}_{2} \mathrm{SO}_{4}$ $10 \%(\mathrm{c})$.

Skrinning fitokimia pada isolat A menunjukkan hasil positif terhadap $\mathrm{KOH} 10 \%$ berwarna kuning pada UV $366 \mathrm{~nm}$ dan $\mathrm{FeCl}_{3}$ menunjukkan warna coklat pada plat KLT. Berdasarkan Baldt (1996), senyawa tersebut diduga merupakan golongan antraquinon.

\section{KESIMPULAN}

Diperoleh Isolat A yang memiliki aktivitas antioksidan yang cukup baik dengan karakteristik kristal putih dengan berat $48 \mathrm{mg}$. Isolat A diduga merupakan golongan senyawa antraquinon.

\section{SARAN}

Dilakukan penentuan struktur isolat A.

\section{DAFTAR PUSTAKA}

Abdelwahab, S. I., dkk. 2010. Chemical composition, antioxidant and antibacterial properties of the essential oils of Etlingera elatior and Cinnamomum pubescens Kochummen. Journal of the Science of Food and Agriculture 2010; 90: 2682-266.

Bladt, S. dan Hildebert Wagne. 1996. Plant Drug Analysis, A Thin Layer Chromatography Atlas, Second edition. Springer Science \& Business Media, Berlin.

Candra, R. A. 2012. Isolasi Dan Uji Aktivitas Antioksidan Senyawa Alkaloid Dari Ekstrak Daun Phoebe declinata Nees. Universitas Indonesia : Jakarta. 
Jaafar, F. M., dkk. 2007. Analysis Of Essential Oils Of Leaves, Stems, Flowers And Rhizomes Of Etlingera Elatior (Jack) R. M. Smith. The Malaysian Journal of Analytical Sciences, Vol 11, No 1 (2007): 269-273.

Maimulyanti, A. dan Anton Restu Prihadi. 2015. Chemical Composition, Phytochemical and Antioxidant Activity from Extract of Etlingera elatior Flower from Indonesia. Journal of Pharmacognosy and Phytochemistry 3(6).

Mohamad, H., dkk. 2005. Antioxidative Constituents of Etlingera elatior. Journal of Natural Products 68 (2).

Siregar, E. S. dan Nursahara Pasaribu.2008. Inventarisasi Jenis-Jenis Zingiberaceae Di Hutan Sibayak Sumatera Utara. Jurnal Penelitian Mipa 2(1). 